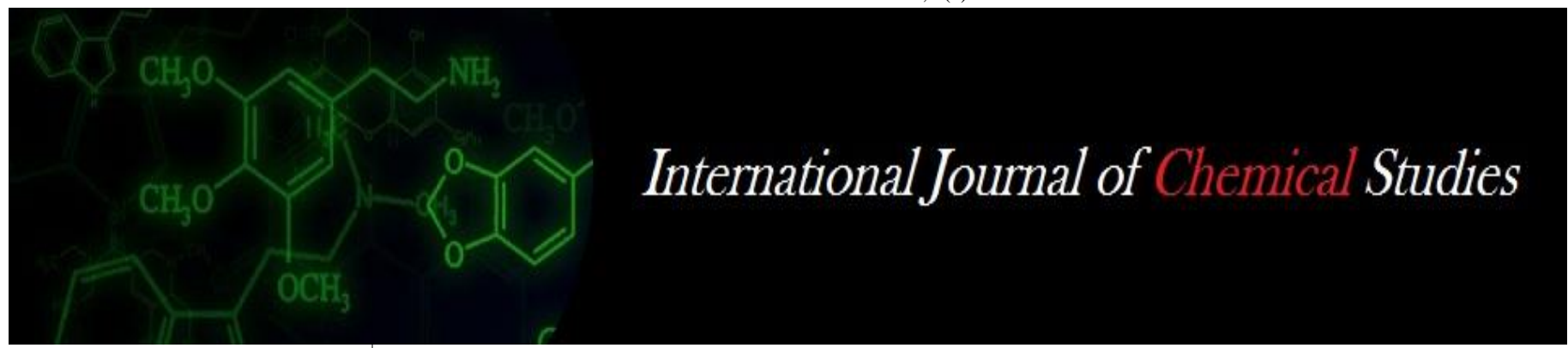

P-ISSN: 2349-8528

E-ISSN: 2321-4902

www.chemijournal.com

IJCS 2020; 8(2): 369-374

(C) 2020 IJCS

Received: 06-01-2020

Accepted: 10-02-2020

\section{Abhishek Amar}

Department of Soil Science and Agricultural Chemistry, Tamil Nadu, Agricultural University Coimbatore, Tamil Nadu, India

\section{R Shanmugasundaram}

Department of Soil Science and Agricultural Chemistry, Tamil Nadu, Agricultural University Coimbatore, Tamil Nadu, India
Corresponding Author: Abhishek Amar

Department of Soil Science and Agricultural Chemistry, Tamil Nadu, Agricultural University Coimbatore, Tamil Nadu, India

\section{The Physio-chemical properties, available sulphur and micro nutrients status in soil of Tiruchirappalli District of Tamil Nadu, India}

\author{
Abhishek Amar and R Shanmugasundaram
}

DOI: https://doi.org/10.22271/chemi.2020.v8.i2f.8795

\begin{abstract}
The study was undertaken with a view to assess the sulphur and micronutrient status in the soils of various blocks of Tiruchirappalli district of Tamil Nadu. The surface soil samples of Tiruchirappalli district were red loamy, acidic to alkaline (5.22 to 9.21) in reaction with salinity level of harmless (0.02 to $\left.1.74 \mathrm{dS} \mathrm{m}^{-1}\right)$ in condition, low to medium in organic carbon $(0.03$ to 0.98$)$ per cent and free calcium carbonate content of non-calcareous to moderately calcareous in nature $(0.05$ to $12.75 \%)$. The available sulphur content was low to high status ( 2.80 to $92.00 \mathrm{mg} \mathrm{kg}^{-1}$ ), the DTPA extractable micronutrients such as $\mathrm{Cu}, \mathrm{Zn}, \mathrm{Mn}, \mathrm{Fe}$ and HWSB content were varied from low to high with range values of 0.03 to $6.38 \mathrm{mg}$ $\mathrm{kg}^{-1}$ for $\mathrm{Cu}, 0.13$ to $4.81 \mathrm{mg} \mathrm{kg}^{-1}$ for $\mathrm{Zn}, 0.21$ to $32.74 \mathrm{mg} \mathrm{kg}^{-1}$ for $\mathrm{Mn}, 2.16$ to $42.05 \mathrm{mg} \mathrm{kg}^{-1}$ for Fe and 0.06 to $3.92 \mathrm{mg} \mathrm{kg}^{-1}$ for HWSB. Regarding available sulphur, it was observed that 11.59 per cent of the surface soils of Tiruchirappalli district are deficient. Zinc deficiency was the predominant in majority of soil samples $(63.82 \%)$ followed by $\mathrm{Cu}(40.11 \%), \mathrm{B}(16.18 \%), \mathrm{Fe}(4.99 \%)$ and $\mathrm{Mn}(3.82 \%)$.
\end{abstract}

Keywords: Soil, organic carbon, sulphur, micro nutrients

\section{Introduction}

Agriculture is a very important sector for sustained growth of Indian economy. Soil is the basic natural resource for crop production and it supplies essential nutrients for plant growth, the food security and necessary components of human and animal food and the nutritional security of the country. However continuous cropping of high yielding varieties without proper substitution of inorganic fertilizers, non-addition of micronutrients, and less or no application of organic manures have caused excessive removal of essential nutrients from the soil reserves that eventually led to the deficiencies of micronutrients in soils. The deficiency may either be primarily due to their low contents or secondarily by soil factor that reduce the availability (Sharma and Chaudhary, 2007) ${ }^{[15]}$. Micronutrients are as essential as macronutrients but required in smaller quantities by plants. Crop growth, yield and quality of many crops may be affected if any one of the essential micronutrients is lacking in soil.

Sulphur is the fourth major nutrient element after nitrogen, phosphorus and potassium. Introduction of high yielding crop varieties, intensive and multiple cropping and decreased use of farmyard manure seem to have lead to a wide occurrence of sulphur deficiency and diverted the attention of the researchers towards this hitherto neglected element. It has been mentioned by Kanwar (1976) ${ }^{[7]}$ that intensive farming practices are followed and use of concentrated fertilizers free from sulphur become more popular, the areas which are now presumed to contain adequate amount of sulphur may also begin to show sulphur deficiency. In countries like India where intensive cultivation is being followed, sulphur is one of the element that must not be overlooked. Sulphur deficiency in soils of Indian states varies from 5 to 83 per cent with an overall mean of 41 per cent (Singh, 2001) ${ }^{[16]}$. In India, despite the fact that macronutrients had a remarkable impact on crop production, devoid of micronutrients in the production system has caused excessive removal from the soil reserves that eventually led to the deficiencies of micronutrients in soils. It has been reported that the occurrence of $\mathrm{Zn}, \mathrm{Fe}$, $\mathrm{Cu}$ and $\mathrm{Mn}$ deficiencies was to an extent of $49 \%, 12 \%, 5 \%$ and 3\%, respectively in India (Singh and Saha, 1995) ${ }^{[13]}$. 


\section{Materials and Methods}

The geo-referenced surface soil samples were collected from the villages of Tiruchirappalli district to assess the available sulphur and micronutrient status, preparation of thematic maps based on the nutrient availability for depicting the severity of sulphur and micronutrient status at blocks level. The particulars of study area, the method of soil sample collection, mapping of sulphur and micronutrient status at block level.

\section{Description of study area}

The Tiruchirappalli district of Tamil Nadu extends over an area of 4, 40,383 hectares. It is geographically bounded by Salem district in the North, Thanjavur district in the East, Sivaganga and Madurai district in the South and Karur district in the West. Geographically, it lies between $78^{\circ} 10^{\prime}$ to $79^{\circ} 5^{\prime}$ Eastern longitude and $10^{\circ} 15^{\prime}$ to $11^{\circ} 2^{\prime}$ 'Northern latitude with altitude of $90 \mathrm{~m}$.

The average annual rainfall is $842.6 \mathrm{~mm}$. The contribution of South West, North East monsoons, winter rainfall and summer rainfall are $32.43 \%, 46.85 \%, 4.8 \%$ and $15.90 \%$ respectively. There are two cropping seasons viz. Kuruvai (June-July) and Samba (August).

Major portion of the district is covered by plain topography. Gneissic group of rocks of Archean period consisting of granitoid mica gneiss, granitic gneiss leptinites, mixed and composite gneiss are found at different places. The dominant minerals found in the district are limestone, gypsum, garnet sand and limonite. The crystalline lime stones of Precambrian age are mainly distributed in parts of Tiruchirappalli. Deep black is the predominant soil in the district accounting for 32.2 percent followed by the deep red soil with 25.12 percent. The present study area comprises the Tiruchirappalli district consisting of 9 taluks, 14 blocks and 408 Panchayat villages. The geographic area of the taluks and number of samples comprising the Tiruchirappalli district.

\section{Collection and processing of geo-referenced surface soil samples}

Totally 1584 geo-referenced surface soil samples covering all the villages in fourteen blocks of Tiruchirappalli district were collected randomly at $0-15 \mathrm{~cm}$ depth by adopting the standard procedures of soil sample collection. The Global Positioning System (GPS) data (Eastern Longitude and Northern Latitude) were collected from each sampling sites distributed over the entire Tiruchirappalli district by using GPS.

The collected soil samples were air dried, gently bound, sieved (2 $\mathrm{mm}$ sieve) and preserved in serially labeled polythene bags for further analysis. Locations of soil sampling sites of Tiruchirappalli district were marked on base map 1: 50,000 scale prepared from State Revenue Maps and digitized using Arc-GIS.

\section{Soil analysis}

The surface soil samples were analyzed for various soil properties by adopting standard procedures. The methods employed are described below.

\section{a. Soil reaction $(\mathrm{pH})$}

The $\mathrm{pH}$ of soil was estimated by employing potentiometry method using soil water suspension in the ratio of $1: 2.5$ (Jackson, 1973) ${ }^{[6]}$.

\section{b. Electrical conductivity (EC)}

The electrical conductivity of soil was estimated by employing conductometry method in the soil water suspension in the ratio of 1: 2.5 (Jackson, 1973) ${ }^{[6]}$.

\section{c. Organic carbon $(\mathrm{OC})$}

The organic carbon content of soil was estimated by chromic acid wet digestion method (Walkley and Black, 1934) ${ }^{[17]}$.
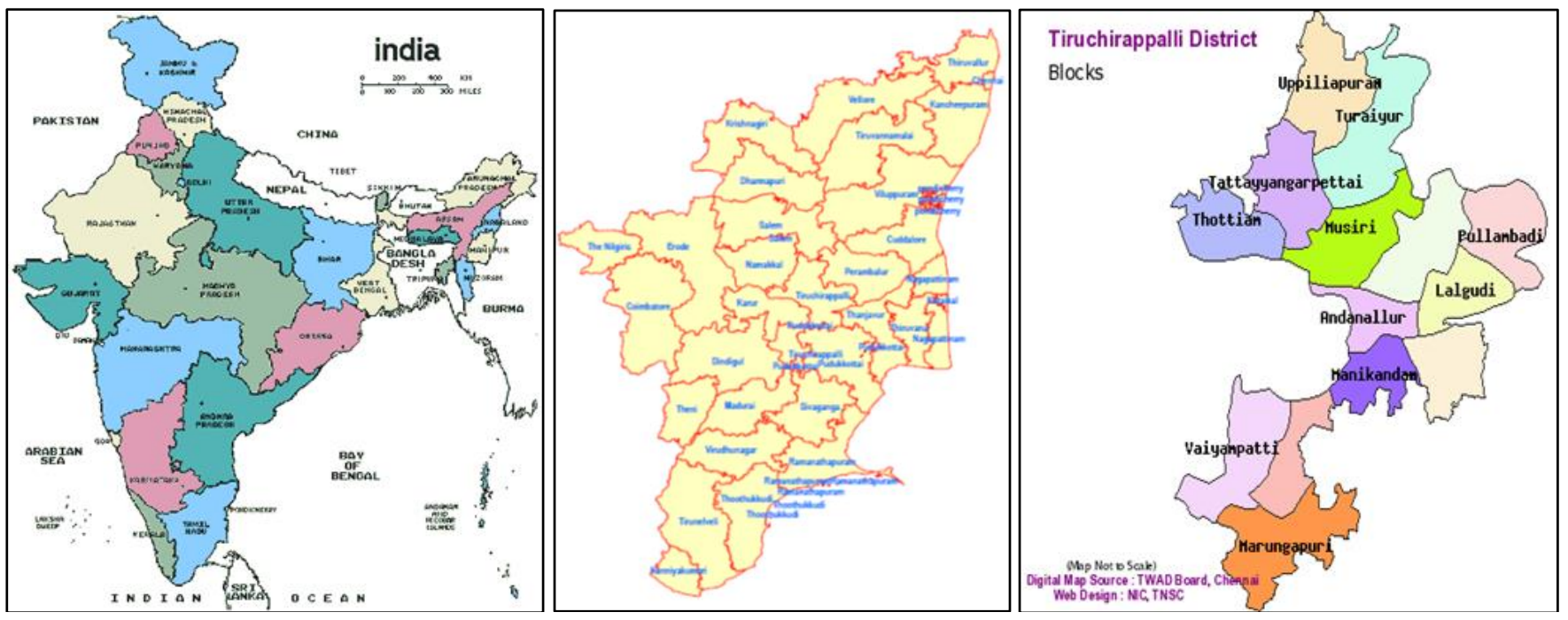

Fig 1: Location map of Tiruchirappalli district

\section{d. Calcium Carbonate $\left(\mathrm{CaCO}_{3}\right)$}

The soil free calcium carbonate was determined by employing rapid titration method (Piper, 1966) ${ }^{[12]}$.

\section{e. Available Sulphur}

The available sulphur content of the soil was estimated by $0.15 \% \mathrm{CaCl}_{2}$ method. $5 \mathrm{~g}$ of soil was Shaked with $50 \mathrm{ml}$ of $0.15 \% \mathrm{CaCl}_{2}$ for 30 minutes in a reciprocating shaker. An aliquot of $2.5 \mathrm{ml}$ of extract was pipetted out into a $25 \mathrm{ml}$ volumetric flask and $10 \mathrm{ml}$ sodium acetate - acetic acid buffer, $1 \mathrm{~g} \mathrm{BaCl}_{2}$ and $1 \mathrm{ml}$ freshly prepared gum acacia were added. The volume was made up with distilled water and shaken well, and then the absorbance of this solution was read in a spectrophotometer at $420 \mathrm{~nm}$ after adjusting the meter to zero per unit absorbance with the blank and the sulphate 
content was calculated using the standard curve (Williams and Steinberg, 1959) ${ }^{[19]}$.

\section{f. DTPA extractable micronutrients}

The available micronutrients were extracted with DTPA (0.005 M Diethylene Triamine Penta Acetic Acid + 0.1 M Triethanolamine $+0.01 \mathrm{M} \mathrm{CaC1}_{2}$ ) extractant adjusted to $\mathrm{pH}$ $7.3 \pm 0.5$ using $1: 1$ dilute $\mathrm{HCl}$ at $1: 2$ ratio (Soil: DTPAextractant) after shaking for two hours, filtered through Whatman No.42 filter paper. The DTPA extractable copper, zinc, manganese and iron were estimated in the extractant using Atomic Absorption Spectrometer (Lindsay and Norvell, $1978)^{[8]}$.

\section{g. Available boron}

Azomethine-H solution was prepared by dissolving $0.45 \mathrm{~g}$ of 4-methoxy azomethine-H reagent in $100 \mathrm{ml}$ of one percent ascorbic acid. The buffer solution was prepared by dissolving
$250 \mathrm{~g}$ of ammonium acetate and $15 \mathrm{~g}$ of Di-Sodium salt of EDTA (Ethylene Diamine Tetra Acetic acid) in $400 \mathrm{ml}$ of double distilled water. All the reagents were dissolved and $125 \mathrm{ml}$ of acetic acid was added to the solution and mixed thoroughly (Bingham, 1982) ${ }^{[3]}$.

Twenty grams of soil sample was transferred to a conical flask, to which $40 \mathrm{ml}$ of double distilled water and $0.5 \mathrm{~g}$ of activated charcoal were added. The contents were kept in a water bath maintained at $60^{\circ} \mathrm{C}$ for half an hour and filtered through Whatman No.42 filter paper. $5 \mathrm{ml}$ of filtrate was pipetted out into $25 \mathrm{ml}$ volumetric flask, to which $4 \mathrm{ml}$ of buffer and four $\mathrm{ml}$ of Azomethine $-\mathrm{H}$ were added and allowed for half an hour for colour development. The volume was made up to $25 \mathrm{ml}$ and the color intensity was measured at $420 \mathrm{~nm}$ using UV-Visible Spectrophotometer (Berger and Troug, 1945) ${ }^{[17]}$.

Table 1: Proforma for soil sampling site descriptions

\begin{tabular}{|c|c|c|}
\hline Soil Sample No & \multicolumn{2}{|r|}{ Sampling Date } \\
\hline \multicolumn{3}{|c|}{ Soil sample details } \\
\hline 1. & \multicolumn{2}{|l|}{ District } \\
\hline 2. & Taluk & \\
\hline 3. & Block & \\
\hline 4. & \multirow{2}{*}{$\begin{array}{l}\text { Revenue Village Name } \\
\text { Geo- coordinates by GPS }\end{array}$} & \\
\hline 5. & & $\mathrm{~N}^{\circ}$ \\
\hline 6. & Field survey No. & \\
\hline 7. & Field location / land mark & \\
\hline 8. & \multirow{2}{*}{$\begin{array}{c}\text { Major soil type } \\
\text { Field condition at the time of soil sampling }\end{array}$} & \\
\hline 9. & & Dry: Wet: Fallow: Cropped: \\
\hline \multicolumn{3}{|c|}{ Farmer details } \\
\hline 10. & \multirow{2}{*}{$\frac{\text { Name of the farmer }}{\text { Address }}$} & Mr. \\
\hline 11. & & \\
\hline \multicolumn{3}{|c|}{ Crop and field details } \\
\hline 12. & Major crops cultivated & \\
\hline 13. & Cropping sequence & \\
\hline 14. & System of cultivation & Dry: Wet: Irrigated: \\
\hline \multirow{2}{*}{15.} & \multirow{2}{*}{ Fertilization practices } & N: P: K: NPK Only: \\
\hline & & NPK + Micronutrients: No practices: \\
\hline 16. & GM/OM practices & Yes: No: \\
\hline 17. & Source of irrigation & River: Tank / Lake: Canal: Bore well: Well: \\
\hline 18. & If any other & \\
\hline
\end{tabular}

Table 2: Number of geo-referenced soil samples collected from different blocks of Tiruchirappalli district

\begin{tabular}{|c|c|c|c|c|}
\hline S. No. & Taluk & Block & No. of panchayat villages & Number of samples \\
\hline \multirow{2}{*}{1.} & \multirow{2}{*}{ Lalgudi } & Lalgudi & 43 & 172 \\
\hline & & Pullambadi & 32 & 128 \\
\hline \multirow{3}{*}{2.} & \multirow{3}{*}{ Manapparai } & Manapparai & 21 & 84 \\
\hline & & Vaiyampatti & 18 & 72 \\
\hline & & Marungapuri & 49 & 196 \\
\hline 3. & Manachanallur & Manachanallur & 31 & 124 \\
\hline \multirow{2}{*}{4.} & \multirow{2}{*}{ Musiri } & Musiri & 32 & 128 \\
\hline & & Thathayangarpettai & 26 & 104 \\
\hline 5. & Srirangam & Andanallur & 21 & 84 \\
\hline 6. & Tiruchirappalli & Manikandam & 22 & 88 \\
\hline 7. & Thottiyam & Thottiyam & 26 & 104 \\
\hline \multirow{2}{*}{8.} & \multirow{2}{*}{ Thuraiyur } & Thuraiyur & 34 & 136 \\
\hline & & Uppliliapuram & 18 & 72 \\
\hline 9. & Thiruverumbur & Thiruverumbur & 23 & 92 \\
\hline \multicolumn{3}{|c|}{ Total } & 396 & 1584 \\
\hline
\end{tabular}




\section{Categorizations of samples based on critical limits}

The analytical results of each soil samples were categorized into low, medium and high categories based on the critical limit of available sulphur and micronutrient. The percent sample at each category was assessed for each element at block level.

Table 3: Critical limits $\left(\mathrm{mg} \mathrm{kg}^{-1}\right)$ of available sulphur and micronutrients.

\begin{tabular}{|c|c|c|c|}
\hline Element & Low (Deficient) & Medium (Moderate) & High (Sufficient) \\
\hline Sulphur & $<10$ & $10-15$ & $>15$ \\
\hline Copper & $<1.2$ & $1.2-1.8$ & $>1.8$ \\
\hline Zinc & $<1.2$ & $1.2-1.8$ & $>1.8$ \\
\hline Manganese & $<2.0$ & $2.0-4.0$ & $>4.0$ \\
\hline Iron & $<3.7$ & $3.7-8.0$ & $>8.0$ \\
\hline Boron & $<0.46$ & $0.46-1.0$ & 1.0 \\
\hline
\end{tabular}

(Anon., 2003) ${ }^{[2]}$

\section{Statistical analysis}

The database on the analysis of soil available micronutrient content were developed using Microsoft Excel page, in order to determine the inter relationship between available micronutrients and soil characteristics and the simple correlation was used (Sundar Raj et al., 1972). The simple correlation (bi-variate analysis) was executed by using SPSS 161.0 data editor software.

\section{Results and Discussion}

The present study was conducted with the major objectives of assessment of each block in Tiruchirappalli district for available micronutrient status, to determine the relationship with soil characteristics and available sulphur and micronutrients.

\section{Surface soil characteristics of Tiruchirappalli district \\ 1. Soil pH}

The $\mathrm{pH}$ of the surface soils of different blocks in Tiruchirappalli district varied widely from 5.22 to 9.21 with overall mean value of 7.43. However, majority of blocks had neutral $\mathrm{pH}$. Out of fourteen blocks the lowest mean $\mathrm{pH}$ of 7.12 and the highest mean $\mathrm{pH}$ of 7.75 was recorded in Musiri and Thottiyam block respectively. The mean $\mathrm{pH}$ values recorded were 7.58 in Lalgudi, 7.37 in Pullambadi, 7.42 in Vaiyampatti, 7.23 in Marungapuri, 7.63 in Manachanallur, 7.41 in Thathayangarpettai, 7.27 in Andanallur, 7.59 in Manikandam, 7.53 in Thuraiyur, 7.37 in Uppliliapuram, 7.34 in Manapparai and 7.42 in Thiruverumbur.

\section{Electrical Conductivity}

The electrical conductivity of the surface soils ranged from 0.02 to $1.74 \mathrm{dS} \mathrm{m}^{-1}$, with an overall mean value of $0.38 \mathrm{dS} \mathrm{m}^{-}$

1. In general, almost all soils had low level of salinity and posed no problem in the selection of crops. Out of fourteen blocks lowest mean EC of $0.20 \mathrm{dS} \mathrm{m}^{-1}$ and the highest mean EC of $0.52 \mathrm{dS} \mathrm{m} \mathrm{m}^{-1}$ was recorded in Thiruverumbur and Uppliliapuram respectively. The mean EC values recorded were 0.42 in Lalgudi, $0.46 \mathrm{dS} \mathrm{m}^{-1}$ in Pullambadi, $0.51 \mathrm{dS} \mathrm{m}^{-1}$ in Vaiyampatti, $0.30 \mathrm{dS} \mathrm{m} \mathrm{m}^{-1}$ in Marungapuri, $0.37 \mathrm{dS} \mathrm{m}^{-1}$ in Manachanallur, $0.43 \mathrm{dS} \mathrm{m}^{-1}$ in Musiri, $0.46 \mathrm{dS} \mathrm{m}^{-1}$ in Thathayangarpettai, $0.36 \mathrm{dS} \mathrm{m} \mathrm{m}^{-1}$ in Andanallur and Manikandam, $0.21 \mathrm{dS} \mathrm{m}^{-1}$ in Thottiyam, $0.31 \mathrm{dS} \mathrm{m}^{-1}$ in Thuraiyur and $0.46 \mathrm{dS} \mathrm{m}^{-1}$ in Manapparai.

\section{Organic Carbon}

The organic carbon content of surface soils in different blocks of Tiruchirappalli district ranged from 0.03 to 0.98 percent.
Based on low $(<0.50 \%)$, medium $(0.50-0.75 \%)$ and high ( $>$ $0.75 \%$ ) status, all blocks fall under medium levels of organic carbon with an overall mean value of $0.54 \%$. Manapparai block had the highest mean value of 0.68 percent of organic carbon content followed by Uppliliapuram $(0.67 \%)$, Lalgudi block $(0.58 \%)$ and Pullambadi $(0.54 \%)$. Other blocks like Vaiyampatti (0.61\%), Marungapuri and Musiri (0.49\%), Manachanallur and Thathayangarpettai $(0.55 \%)$, Manikandam $(0.41 \%)$, Thuraiyur and Andanallur $(0.54 \%)$, Thottiyam and Thiruverumbur recorded similar values of $0.51 \%$.

\section{Free Calcium Carbonate}

The free calcium carbonate content of surface soils in Tiruchirappalli district was in the range of 0.05 to 12.75 percent. Among all the blocks, the lowest mean value for $\mathrm{CaCO}_{3}$ of 2.37 percent was registered in Andanallur block while the Thathayangarpettai block had recorded the highest calcium carbonate content of 7.69 percent. The mean calcium carbonate content recorded were, $6.03 \%$ in Lalgudi, $5.62 \%$ in Pullambadi, 6.92\% Vaiyampatti, 5.24\% in Marungapuri and Musiri, 5.93\% in Manachanallur, 5.27\% in Manikandam, $4.61 \%$ in Thottiyam, $5.59 \%$ in Thuraiyur, $6.22 \%$ in Uppliliapuram, $6.69 \%$ in Manapparai and $5.25 \%$ in Thiruverumbur.

\section{Available Sulphur}

The available sulphur in Tiruchirappalli district ranged from 2.80 to $92.00 \mathrm{mg} \mathrm{kg}^{-1}$, with a mean of $23.62 \mathrm{mg} \mathrm{kg}^{-1}$, which falls under high category. Among all the blocks the lowest mean value of available sulphur of $16.12 \mathrm{mg} \mathrm{kg}^{-1}$ was recorded in Musiri block while the Marungapuri block had recorded the highest available sulphur content of $43.63 \mathrm{mg} \mathrm{kg}^{-}$ 1. The remaining blocks like Lalgudi, Pullambadi, Vaiyampatti, Manachanallur, Thathayangarpettai, Andanallur, Manikandam, Thottiyam, Thuraiyur, Uppliliapuram, Manapparai and Thiruverumbur had S content of 21.04, 23.38, 25.07, 21.14, 17.65, 18.47, 19.99, 21.45, 29.69, 23.11, 19.19 and $30.76 \mathrm{mg} \mathrm{kg}^{-1}$ respectively.

\section{Available Micronutrients 6.1. Available Copper}

The content of DTPA-Cu in the soils of Tiruchirappalli district ranged from 0.03 to $6.38 \mathrm{mg} \mathrm{kg}^{-1}$ with mean value of $1.51 \mathrm{mg} \mathrm{kg}^{-1}$. The highest mean value of $2.62 \mathrm{mg} \mathrm{kg}^{-1}$ was recorded in soils of Manikandam block and the lowest mean value was recorded in Uppliliapuram $\left(0.92 \mathrm{mg} \mathrm{kg}^{-1}\right)$ and Thuraiyur $\left(0.97 \mathrm{mg} \mathrm{kg}^{-1}\right)$. The remaining blocks like Lalgudi, Pullambadi, Vaiyampatti, Marungapuri, Manachanallur, Musiri, Thathayangarpettai, Andanallur, Thottiyam, Manapparai, and Thiruverumbur were found to have $\mathrm{Cu}$ content of 1.47, 1.48, 1.29, 1.94, 1.44, 1.57, 1.35, 1.21, 1.67, 1.92 and $1.35 \mathrm{mg} \mathrm{kg}^{-1}$ respectively.

\subsection{Available Zinc}

The DTPA-Zn content of soils of Tiruchirappalli district ranged from 0.013 to $4.81 \mathrm{mg} \mathrm{kg}^{-1}$ with mean value of 1.09 $\mathrm{mg} \mathrm{kg}^{-1}$. The soils of Thathayangarpettai $\left(1.92 \mathrm{mg} \mathrm{kg}^{-1}\right)$ block recorded the highest mean value for DTPA-Zn and lowest mean value recorded in soil of Musiri block $\left(0.72 \mathrm{mg} \mathrm{kg}^{-1}\right)$. The remaining blocks like Lalgudi, Pullambadi, Vaiyampatti, Marungapuri, Manachanallur, Andanallur, Manikandam, Thottiyam, Thuraiyur, Uppliliapuram, Manapparai and Thiruverumbur recorded $\mathrm{Zn}$ content of $0.89,1.09,0.86,0.89$, $1.01,1.77,1.20,1.30,0.97,0.98,0.80$ and $0.98 \mathrm{mg} \mathrm{kg}^{-1}$ respectively. 


\subsection{Available Manganese}

The content of DTPA-Mn ranged from 0.21 to $32.74 \mathrm{mg} \mathrm{kg}^{-1}$. The soils of Andanallur block recorded the highest mean value $\left(21.68 \mathrm{mg} \mathrm{kg}^{-1}\right)$ followed by Thathayangarpettai (18.08 mg $\mathrm{kg}^{-1}$ ), while lowest mean value was recorded in Marungapuri (8.55 $\mathrm{mg} \mathrm{kg}^{-1}$ ) block. Other blocks like Lalgudi, Pullambadi, Vaiyampatti, Manachanallur, Musiri, Manikandam, Thottiyam, Thuraiyur, Uppliliapuram, Manapparai and Thiruverumbur recorded 13.86, 13.72, 12.14, $13.49,16.82,10.32,12.80,10.75,14.70,13.93$ and $11.39 \mathrm{mg}$ $\mathrm{kg}^{-1}$ of DTPA-Mn respectively.

\subsection{Available Iron}

The available iron varied from 2.16 to $42.05 \mathrm{mg} \mathrm{kg}^{-1}$. The highest mean value was observed in Thottiyam $\left(16.66 \mathrm{mg} \mathrm{kg}^{-}\right.$ $\left.{ }^{1}\right)$ followed by Vaiyampatti $\left(16.63 \mathrm{mg} \mathrm{kg}^{-1}\right)$ and the lowest mean value was in Musiri block (10.29 mg kg-1). The remaining blocks viz., Lalgudi, Pullambadi, Marungapuri, Manachanallur, Thathayangarpettai, Andanallur, Manikandam, Thuraiyur, Uppliliapuram, Manapparai and Thiruverumbur recorded 14.88, 14.38, 15.75, 14.53, 15.98, $13.13,16.15,15.99,13.23,13.54$ and $13.04 \mathrm{mg} \mathrm{kg}{ }^{-1}$ respectively.

\subsection{Available Boron}

The hot water soluble boron in the soils of Tiruchirappalli district varied from 0.06 to $3.92 \mathrm{mg} \mathrm{kg}^{-1}$ with mean value of $1.03 \mathrm{mg} \mathrm{kg}^{-1}$. The soils of Marungapuri block registered the highest mean value of $1.58 \mathrm{mg} \mathrm{kg}^{-1}$ respectively. Among the blocks, Manapparai had the lowest mean value of $0.61 \mathrm{mg} \mathrm{kg}$ ${ }^{1}$ for hot water extractable boron. Other blocks like Lalgudi, Pullambadi, Vaiyampatti, Manachanallur, Musiri, Thathayangarpettai, Andanallur, Manikandam, Thottiyam, Thuraiyur, Uppliliapuram, and Thiruverumbur recorded 0.94 , $1.10,1.02,1.58,0.94,0.94,0.87,0.86,1.40,0.97,1.11,0.87$, and $1.23 \mathrm{mg} \mathrm{kg}^{-1}$ respectively.

The soils $\mathrm{pH}$ of different blocks was acidic to alkaline $(\mathrm{pH}$ 5.22 to 9.21) with mean of 7.43. The low $\mathrm{pH}$ was observed in Maniyankuruchi village in Marungapuri block which may be due to migration of bases, the higher $\mathrm{pH}$ in Pirattiyur village of Manikandam block may be due to high degree of base saturation. Similar finding were also reported by Gajbe et al. (1976) ${ }^{[5]}$. Among this, a majority of the samples fall under neutral category which is ideally suited for cultivation of wide range of crops.

The electrical conductivity of Tiruchirappalli district ranged from $0.02-1.74 \mathrm{dS} \mathrm{m}^{-1}$, with a mean of $0.38 \mathrm{dS} \mathrm{m}^{-1}$. The lowest value of EC $\left(0.02 \mathrm{dS} \mathrm{m}^{-1}\right)$ was recorded in almost all the blocks and the highest $\left(1.74 \mathrm{dS} \mathrm{m}^{-1}\right)$ in Alunthur village of Manikandam block.

The organic carbon content in the soil of Tiruchirappalli district was in the range of low to high status, but majority of the samples were in medium range $(0.50 \%)$ for all the 14 blocks. The lowest percentage of organic carbon $(0.03 \%)$ was recorded in Algapuri villages of Upililiapuram block. The lower organic carbon content of soil may be ascribed to higher temperature of Manikandam block which hasten the rate of oxidation of organic matter. The lower organic carbon content in surface soil may be due to rapid oxidation and decomposition of organic matter (Saha et al. 1996, Mustapha et al., 2011) ${ }^{[13,9]}$.

The mean free $\mathrm{CaCO}_{3}$ content was 5.61 percent, most of the samples analyzed indicate that the soils are slightly calcareous as majority of the samples have slight free lime content. The lowest value $(0.50 \%)$ was recorded in Nammbukuruchi village of Pullambadi block and the highest (12.75\%) was observed in Moovanur villages of Musiri block. This could be due to calcification process in the soils as reported by Pandey et al. $(2000)^{[10]}$.

\section{Available micronutrient status \\ 1. Available Sulphur}

Regarding available sulphur, 66.82 percent samples were found to be high. The available sulphur ranged from 2.80$92.00 \mathrm{mg} \mathrm{kg}^{-1}$ in the soils of different blocks of the study area with an average of $23.62 \mathrm{mg} \mathrm{kg}^{-1}$. The lowest quantity $(2.80$ $\mathrm{mg} \mathrm{kg}^{-1}$ ) was recorded in Kottapalayam village of Upililiapuram and the higher content was recorded in Orathur village (92.00 mg kg-1) of Pullambadi block. The higher concentration of available sulphur in these soils may be due to continous addition of $\mathrm{S}$ containing agrochemicals, farm residues and organic manures. This finding are in agreement with Patel and Patel (2008) ${ }^{[11]}$.

\section{Available Copper}

The available $\mathrm{Cu}$ ranged between 0.06 to $6.38 \mathrm{mg} \mathrm{kg}^{-1}$ in the soils of different blocks of the study area with an average value of $1.51 \mathrm{mg} \mathrm{kg}^{-1}$. Considering $1.2 \mathrm{mg} \mathrm{kg}^{-1}$ as the critical limit for available copper in the soil (Anon, 2003) ${ }^{[2]}$, the copper status was found to be marginal, as 40.11 percent of the samples were found to be with low copper content. The lowest value $\left(0.06 \mathrm{mg} \mathrm{kg}^{-1}\right)$ was recorded in Balkrishnampatti village of Upililiapuram and the highest $\left(6.38 \mathrm{mg} \mathrm{kg}^{-1}\right)$ was recorded in Sitambhur village of Musiri block. The data reveals that available $\mathrm{Cu}$ is low for Tiruchirappalli district. This might be due to high amount of organic matter content. These results are in conformation with finding of Sharma et al. (2004) ${ }^{[14]}$.

\section{Available Zinc}

A wide variation in DTPA-Zn content of various blocks of Tiruchirappalli district was observed which varied from 0.13 to $4.81 \mathrm{mg} \mathrm{kg}^{-1}$ with a mean value of $1.51 \mathrm{mg} \mathrm{kg}^{-1}$ soil. The lowest value $\left(0.13 \mathrm{mg} \mathrm{kg}^{-1}\right)$ was noticed in A. Rettiyapatti village of Vayamptti blocks and the highest value $(4.23 \mathrm{mg}$ $\mathrm{kg}^{-1}$ ) in T. Puthur village of Musiri block. Considering the critical limit of available $\mathrm{Zn}$ which is $1.2 \mathrm{mg} \mathrm{kg} \mathrm{kg}^{-1}$ (Krishnaswamy et al., 1994).

\section{Available Manganese}

The content of available manganese varied from 0.21 to 32.74 $\mathrm{mg} \mathrm{kg} \mathrm{kg}^{-1}$ with an average of $13.73 \mathrm{mg} \mathrm{kg}^{-1}$ soil during the survey. As per the critical limit of $2 \mathrm{mg} \mathrm{kg}^{-1}$ in Tiruchirappalli district concerned, 84.85 percent of total samples analyzed were sufficient in manganese content to support crop growth. Higher availability of Mn may be because these regions are dominant in rice growing areas and this status is similar to the findings of Weerarathana (1989) ${ }^{[18]}$.

\section{Available Iron}

The content of DTPA-Fe varied from 2.16 to $42.05 \mathrm{mg} \mathrm{kg}^{-1}$ with an average of $14.58 \mathrm{mg} \mathrm{kg}^{-1}$ in soil. The DTPA-Fe was found to be sufficient (>3.7 mg $\left.\mathrm{kg}^{-1}\right)$ in 95.01 percent samples of this district. Among the blocks studied, Thottiyam and Vaiyampatti blocks showed the 
highest mean for number of samples with respect to available $\mathrm{Fe}$. This can be attributed to low amount of $\mathrm{CaCO}_{3}$ and medium amount of organic carbon present in soils of this block. Increase in available $\mathrm{Fe}$ in solution could be attributed to the formation of complexes of $\mathrm{Fe}^{2+}$ with organic acids produced during anaerobic decomposition of green manure and also due to sharp decrease in $\mathrm{pH}$ and increase in ionic strength (Ponnamperuma, 1977) ${ }^{[18]}$.

\section{Hot water extractable Boron}

The hot water soluble boron content varied from 0.06 to 3.92 $\mathrm{mg} \mathrm{kg}{ }^{-1}$ with an overall mean value of $1.03 \mathrm{mg} \mathrm{kg}^{-1}$ in soil of Tiruchirappalli district and 83.40 percent of samples were found to be sufficient ( $>0.46 \mathrm{mg} \mathrm{kg}^{-1}$ soil). Higher $\mathrm{B}$ availability in the soil may be due to inherent higher B content of the soil and favourable soil reaction which was in line with findings of Datta and Munna Ram (1993) [4], Bradford et al. (1996) ${ }^{[4]}$ and Adeboye (2011) ${ }^{[1]}$.

\section{Conclusion}

- The soils of Tiruchirappalli district was found to be acidic to alkaline (pH: $5.22-9.21$ ) in reaction with salinity level harmless to critical (EC: $0.02-1.74 \mathrm{dS} \mathrm{m}^{-}$ $\left.{ }^{1}\right)$. The organic carbon content ranged from low to high $(0.03-0.98 \%)$ and the free $\mathrm{CaCO}_{3}$ content of noncalcareous to moderately calcareous in nature $(0.50-$ $12.75 \%)$.

- The available sulphur content varied from low to high (2.80-92.00), the DTPA extractable micronutrients such as $\mathrm{Fe}, \mathrm{Zn}, \mathrm{Mn}, \mathrm{Cu}$ and HWSB content varied from 2.16 to $42.05 \mathrm{mg} \mathrm{kg}^{-1}, 0.13$ to $4.81 \mathrm{mg} \mathrm{kg}^{-1}, 0.21-32.74 \mathrm{mg} \mathrm{kg}^{-}$ 1, 0.03 to $6.38 \mathrm{mg} \mathrm{kg}^{-1}$ and 0.06 to $3.92 \mathrm{mg} \mathrm{kg}^{-1}$ respectively.

- DTPA-Fe and DTPA-Mn was found to be very high in this district. Only 4.99 per cent sample come under low (deficient) category for DTPA-Fe 3.82 per cent samples were deficient in DTPA-Mn.

- DTPA-Cu was found to be in "Marginal' category for this district. About 40.11 per cent of samples were grouped in low category, whereas 33.67 per cent sample was found to be high in DTPA-Cu.

- DTPA-Zn was low for Tiruchirappalli district. About 63.82 per cent samples were low (deficient) in DTPA-Zn. In Manapparai block, the maximum number $(90.47 \%)$ of samples are low in DTPA-Zn.

- HWSB was adequate for Tiruchirappalli district. Uppliliapuram block (20.83\%) samples was found to contain maximum number of samples under low category and Marungapuri block $(66.66 \%)$ samples was found to contain maximum number of samples under high category.

\section{References}

1. Adeboye MKA. Status of Total and available Boron and Zinc in the Soils of the Gongola River Basin of Nigeria. Sav. J Agric. 2011; 6(1):47-57.

2. Anon. Annual report of the All-India Coordinated Scheme of Micro and Secondary nutrients and polluted elements in the soils and plants, Tamil Nadu Agricultural University, Coimbatore, 2003.

3. Bingham FT. Boron, In: Methods of soil analysis, part 2. Chemical and micro biological properties (A.L. Ed), American Society of Agronomy, Madison. WI. USA, 1982, 431-448.
4. Datta M, Ram M. Status of micronutrients in some soil series of Tripura. J. Indian Bradford, G.H., A.C. Chang, A.L. Page, J.A. Frampton and H. Wright. 1996. Background concentration of trace and major elements in California soils. Berkey: kearncy foundation of soil science, division of agricultural and natural, 1993.

5. Gajbe MV, Londe MG, Varade SB. Soils of Marathwada Agric. Univ. 1976; 1(2-6):55-59.

6. Jackson ML. Soil chemical analysis - An advanced course, Second Edition, University of Wisconsin, Madison, USA, 1973.

7. Kanwar JS. Calcium, magnesium and sulphur. In: Soil Fertility Theory and Practice, Indian Council of Agricultural Research, New Delhi, 1976, 202-228.

8. Lindsay NL, Norvell WA. Development of DTPA soil test for zinc, iron, manganese and copper. Soil Sci. Soc. Am. J. 1978; 42:421-428.

9. Mustapha Voncir SN, Umar S, Abdul NA. Status and distribution of exchangeable micronutrient in Haplic Usterts Akko Government Area, Gombe State, Nigeria. Inter. J Soil Sci. 2011; 33:234-236.

10. Pandey SP, Singh RS, Mishra SK. Availability of phosphorus and sulphur in Inceptisols of Central Uttar Pradesh. J Indian Soc. Soil Sci. 2000; 48:118-121.

11. Patel JC, Patel KC. Profile distribution of different forms of sulphur in prominent soil series of Gujarat. Asian $\mathbf{J}$ Soil Sci. 2008; 3:24-29.

12. Piper CS. Soil and plant analysis. Hans Publishers, Bombay, 1966.

13. Saha PK, Adhikari S, Chatterjee DK. Available iron, copper, zinc and manganese in some fresh water pond soils of Orissa in relation to soil characteristics. J Indian Soc. Soil Sci. 1996; 44:681-684.

14. Sharma BD, Arora H, Kumar R, Nayyar VK. Relationship between soil characteristics, total and Dtpaextractable micronutrients in in ceptisols of Punjab. Comm. Soil Sci. Plant Anal. 2004; 35:799-818.

15. Sharma JC, Chaudhary K. Vertical Distribution of Micronutrient cations in relation to soil characteristics in lower Shiwaliks of Solan district in North-West Himalayas. J Indian Soc. Soil Sci. 2007; 55:40-44.

16. Singh MV. Evaluation of current micronutrient stocks in different agro-ecological zones of India for sustainable crop production. Fertiliser News. 2001; 46:25-42.

17. Walkley A, Black CA. Acid extractable $\mathrm{Zn}$ in soil in relation to the occurrence of $\mathrm{Zn}$ deficiency symptoms of corn: A method of analysis. Soil Sci. Soc. Am. Proceedings, Berger KC, Troug H. 1945. Boron availability in relation to soil reaction and organic matter content. Soil Sci. Soc. Amer. Proc. 1934; 10:113-116.

18. Weerarathana CS. Absorption of manganese under flooded and un-flooded conditions. J Ponnamperuma, F.N. 1977. Behaviour of minor elements in Paddy soils. IIRI, Res. Paper Series. 1989; 8:1-15.

19. Williams $\mathrm{CH}$, Steinbergs H. Soil sulphur fractions as chemical indices of available sulphur in some Australian soils. Australian Agric. Res. 1959; 10:340-352. 